\title{
РЕЗУЛТАТИ ИСТРАЖИВАЊА ЛОКАЛИТЕТА ЕГЕТА (БРЗА ПАЛАНКА) У 2018. И 2019. ГОДИНИ
}

\author{
Перица Шпехар \\ Универзитет у Београду, Филозофски факултет \\ Одељење за археологију, Београд
}

Гордан Јањић

Музеј Крајине, Неготин

\begin{tabular}{r|r} 
e-mail: perica.spehar@gmail.com & Претходно саопштење \\
Примљено: 30. 4. 2020. & УДК: 904:711.559.6”653”(497.11) \\
Прихваћено: 23. 6. 2020. & $902.2(497.11) ” 2018 / 2019 ”$
\end{tabular}

\begin{abstract}
Апстракт: Током 2018. и 2019. године настављена су археолошка истраживања вишеслојног налазишта Егета у близини Брзе Паланке. У првој кампањи спроведена је неинвазивна археолошка проспекиија на простору Утврђена II и његове шире околине. Извриено је геомагнетно снимање на површини од 1 ха, којим је била обухваћена унутрашњост поменуте фортификације, као и простор на коме се могло очекивати постојање некрополе, будући да су ту, према речима мештана, приликом земљаних радова проналажени остаци људских костију. Наредне године, у складу са добијеним резултатима геомагнетне проспекиије, спроведена су ископавана унутар Утврђења II. Том приликом истраживања су спроведена у три сектора димензија 10 х 5 м, од којих су два постављена на претпостављену трасу северног и источног бедема, док је последњи постављен уз јужни бедем, са његове унутрашње стране. Добијени резултати указали су на то да су, у источној половини утврђена и на траси јужног бедема, слојеве потпуно девастирали припадници ЈНА средином 20. века. Сакупљени археолошки материјал указује на постојање позног халштатског, као и интензивног средюовековног слоја. Осим тога, сакупьена је и значајна количина налаза из периода турске доминаиије.
\end{abstract}

Кључне речи: Дунав, лимес, Егета, геомагнетна проспекиија, средњовековни период, период турске доминације

На десној обали Дунава, у атару села Брза Паланка, налазе се остаци три утврђења (Marsigli 1726: Fig. XXXV). Каснији описи овог значајног налазишта потичу из друге половине 19. века (Kanitz 1982, 40-42, fig. 21; Каниц 1985, 454-456). На основу очуваних података из писаних извора, налазиште је идентификовано као античка Егета, важно насеље на раскршћу два главна путна правца у овом делу Царства (Ptol. III 9, 3; It. Ant. 218; Tab. Peut., seg. VII; Mirković 1968, 114-116 са наведеном литературом; Mirković 
$2015,87-89)$. Локалитет је делимично рекогносциран и истражен у склопу заштитних истраживања подузетих приликом изградње хидроелектрана Ђердап I и II у другој половини 20. века. После открића остатака светилишта посвећеног Јупитеру Долихену (Vučković-Todorović 1962, 208-210; Вучковић-Тодоровић 1965; Mirković 2007, 84, Abb. 78; Јањић 2016, 80-85, кат. бр. 47-60), уследила су даља истраживања, током којих је констатовано да је простор Егете коришћен од праисторије до периода турске доминације (Ерцеговић-Павловић, Минић 1984; Петровић 1984; Поповић 1984; Радосављевић 1984; Petrović 1986; Špehar 2011, 40-41, sl. 20). Након паузе од готово 40 година, уследио је наставак истраживања овог локалитета. Том приликом извршено је прецизно геопозиционирање остатака сва три утврђења, одређивање њихових тачних димензија, а утврђена је и њихова међусобна удаљеност. Такође је дефинисан и степен померања обала Дунава, до кога је дошло услед подизања нивоа воде по изградњи хидреоелектране Ђердап II. Том приликом је извршено и геомагнетно снимање Утврђења III и његове непосредне околине, током кога су установљени правци пружања бедема и постојање одбрамбених ровова јужно од фортификације, док су у унутрашњости констатовани остаци грађевина (Шпехар 2018, 57-65, сл. 4-9).

$* * * * * * * * *$

Током новембра 2018. године настављена су археолошка истраживања локалитета Егета, ${ }^{1}$ путем геомагнетних снимања (сл. 1). ${ }^{2}$ Том приликом третирана је унутрашњост Утврђења II, као и део простора између Утврђења II и III, на коме су, према речима мештана, откривани остаци људских скелета приликом земљаних радова. Истраживања су, као и претходне године, спроведена помоћу магнетометра Sensys Datalogger DLM98, који се налазио на колицима са два точка. Геомагнетна снимања су спровођена преко пет сонди, које су се налазиле на удаљености од 0,25 м. Мерене су тачке на сваких 0,1 м, док је калибрација добијених вредности вршена помоћу одометра. Добијени резултати су затим били обрађени кроз софтверске програме Sensys $M A G N E T O, G V S I G$ и $Q G I S$ и преклопљени преко геореференцираних мапа.

Током геомагнетних страживања у унутрашњости Утврђења II, констатоване су камене масе на правцу пружања сва четири бедема, као и по-

\footnotetext{
${ }^{1}$ Чланове екипе чинили су П. Шпехар са Одељења за археологију Филозофског факултета у Београду, Г. Јањић из Музеја Крајине у Неготину и А. Дедић, студент мастер студија на Одељењу за археологију Филозофског факултета у Београду.

${ }^{2}$ Геомагнетно снимање и анализу добијених резултата извршила је специјалистичка фирма A.E.G.I.S Archäologische Dokumentation из Мајнца у Немачкој, коју су представљали П. Мертел и Ј. Пендић.
} 


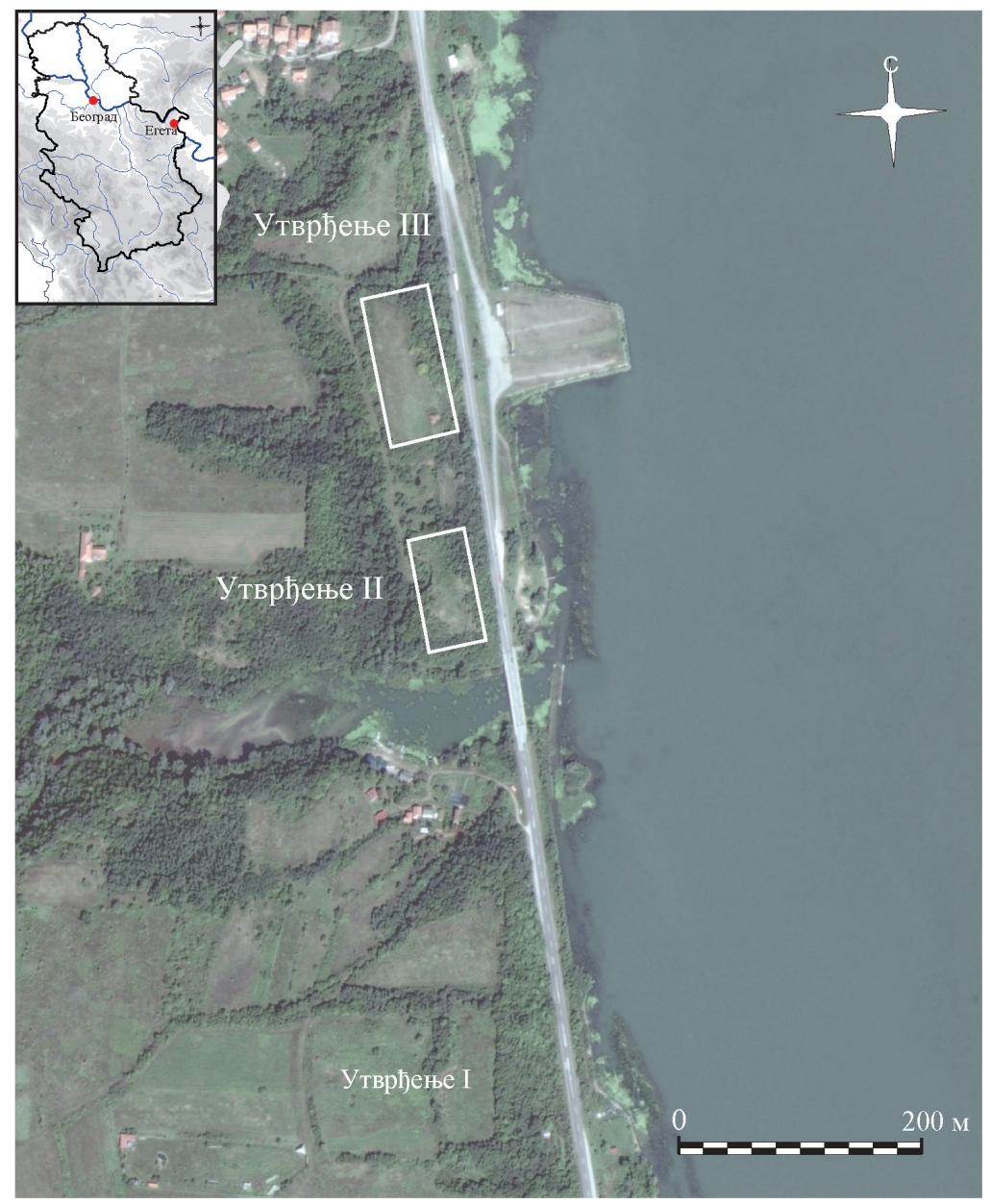

Сл. 1. Зоне истраживане геомагнетном проспекцијом

Fig. 1. Zones researched by geomagnetic prospection

ложај североисточне угаоне куле кружне основе, чији пречник износи око 8 м, као што је случај и са северозападном угаоном кулом, која је делимично археолошки истражена. У унутрашњости утврђења, поред рецентног рова за оптички кабл који пролази кроз средишњи део утврђења по правцу C-J, најдоминантнију откривену структуру представља правоугаона камена конструкција која се налази у централном делу фортификације. Њене димензије износе око 50 х 6 м, при чему је дужом страном оријентисана у правцу C-J. Судећи према геомагнетним снимањима, дебљина зидова ове грађевине износи око 1 м. Осим тога, констатовани су и други, релативно бројни трагови конструкција, махом неправилног овалног облика, чија се дужина 


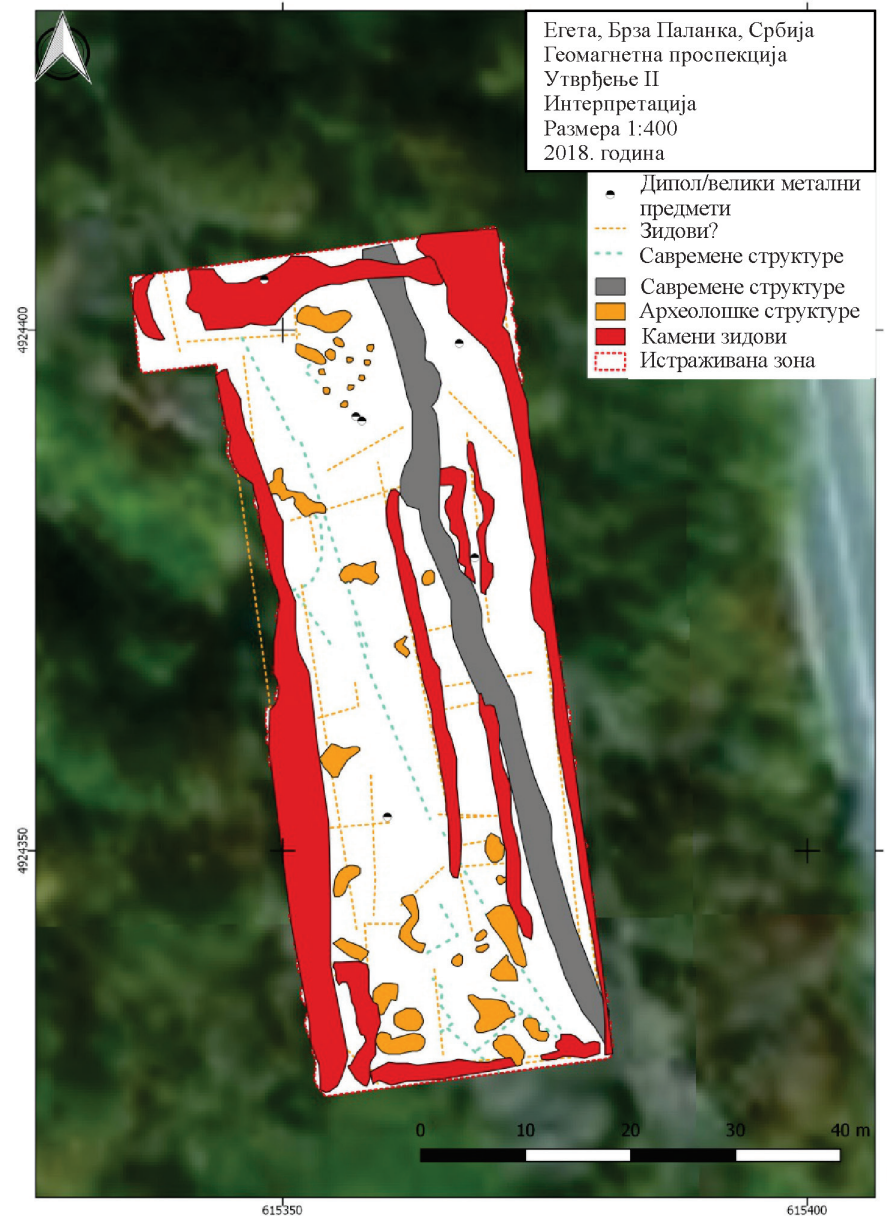

Сл. 2. Резултати геомагнетних снимања на простору Утврђења II

Fig. 2. Results of the geomagnetic surveys of the area of Fortification II

креће измећу 2 и 5 м, док ширина може да варира од 1 до 2 м. Осим тога уочена је и група мањих кружних структура пречника око 1 м, која се налази у зони уз унутрашње лице северног бедема. Иако се поменуте структуре јављају на готово читавој површини утврђења, изузимајући зону уз источни бедем, њихова највећа концентрација је првенствено с унутрашње стране јужног бедема (сл. 2).

Геомагнетна проспекција спроведена на претпостављеној површини некрополе потврдила је даљи правац пружања оптичког кабла, који и овде пролази кроз средишњи део истраживане зоне по правцу С-J. Осим тога, указала је и на постојање бројних могућих археолошких структура на 


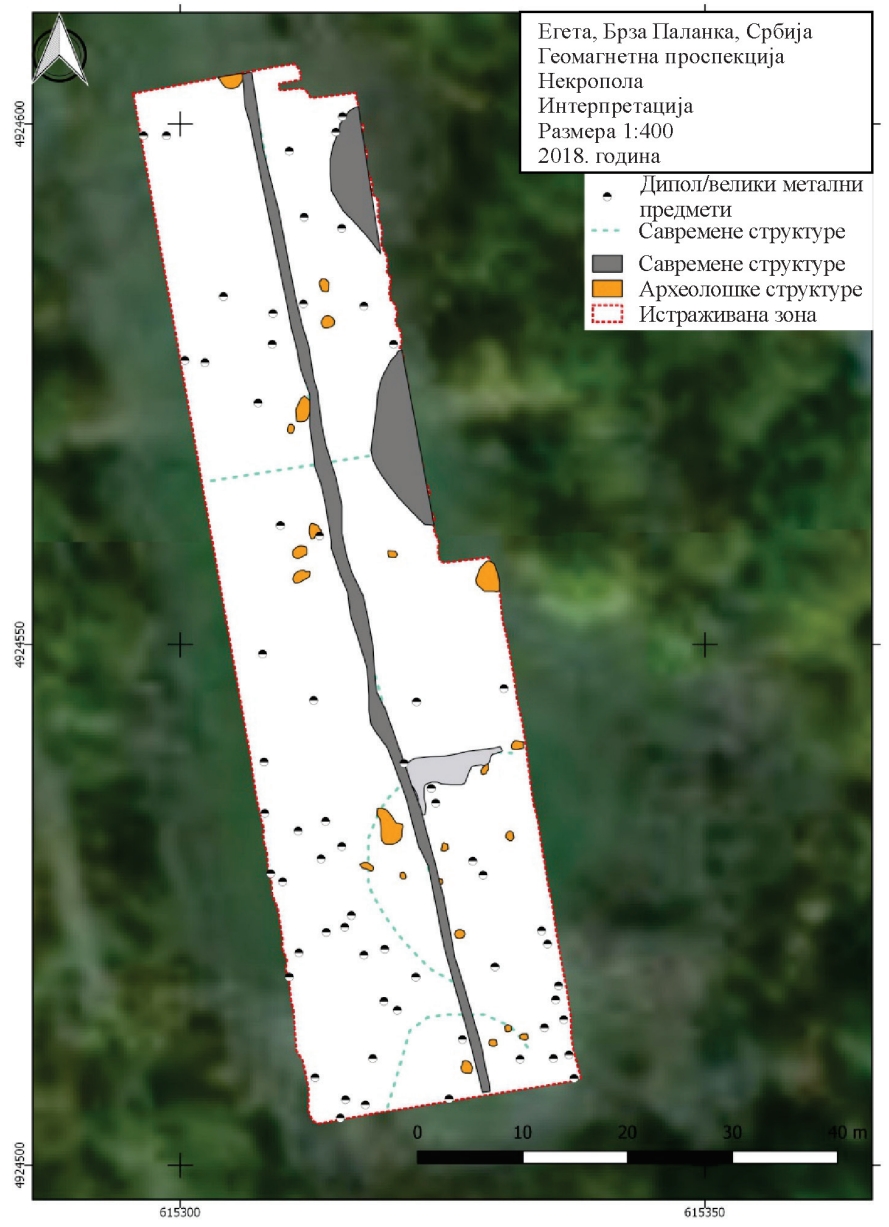

Сл. 3. Резултати геомагнетних снимања на простору претпостављене некрополе

Fig. 3. Results of the geomagnetic surveys of the area of the supposed necropolis

читавој површини која је била предмет геомагнетне проспекције. Резултати снимања не указују да је реч о правоугаоним гробовима или зиданим гробницама истоветне основе, већ о структурама различитих облика и димензиjа. Преовладавају структуре кружног облика, чији пречник најчешће износи око 1 м, мада може достизати и до 3 м. Овалне конструкције пак имају претежно димензије од 1,5 х 1 м, док структуре неправилног облика не прелазе дужину од 3 м. Осим тога, констатовани су и бројни магнетни поремећаји, који би могли да указују на постојање гвоздених предмета већих димензија. Иако се јављају на читавој истраживаној зони, њихова густина је нешто већа у јужном делу (сл. 3). Будући да је ЈНА током педесетих и шездесетих 
година 20. века користила дунавску терасу од Утврђења I до Утврђења II као полигон на коме се налазио и одбрамбени ров (Шпехар 2018, 59), можемо претпоставити да поменуте зоне магнетних поремећаја представљају заправо чауре пушчаних метака или пројектиле мањег калибра, које је користила противваздушна одбрана.

\section{$* * * * * * * * * *$}

Током 2019. године настављена су истраживања локалитета Егета. Овом приликом спроведена су археолошка ископавања у унутрашњости Утврђења II. ${ }^{3}$ Најпре је постављена квадратна мрежа у складу са микротопографским одликама терена, будући да се са три стране платоа на коме је смештена фортификација налази падина, док је са севера приступ нешто лакши. Због тога се теме квадратне мреже, сачињено од квадрата димензија 5 х 5 м, налази код југозападне угаоне куле. Квадрати су означени великим словима абецеде по $x$-оси, односно нумерички по $y$-оси. У току кампање отворена су три сектора означена римским бројевима I-III, постављена на основу резултата геомагнетних снимања и ситуације затечене на терену (сл. 4).

Сектор I, димензија 10 х 5 м, обухвата квадрате D19 и Е19. Својом дужом страном оријентисан је по оси И-3. Постављен је готово управно на северни бедем, чију претпостављену трасу сече. Његова западна ивица налази се уз источну ивицу некадашње сонде у чијој основи се виде остаци поређаног камена, за који се претпоставља да представља северни бедем Утврђења II. Постављањем ове сонде желели су се потврдити подаци о правцу пружања бедема, добијени током ископавања из осамдесетих година 20. века (Петровић 1984, 157-158, сл. 142). Такође, требало је утврдити стратиграфију утврђења, као и тренутак подизања бедема. Током ископавања у сектору I, утврђено је да се испод танког слоја хумуса налази интензивни слој шута сачињен од невезаног кречног малтера беле боје и комада ситног камена, уз спорадичну појаву ситнијих уломака опеке. Реч је по свему судећи о земљи избаченој приликом ранијих ископавања из сонде која се налази западно од Сектора I. У њој је откривена већа концентрација уломака керамике и животињских костију, као и метални налази попут врха стрелице и ножа. Слој шута са ранијих ископавања имао је дебљину око 0,6 м у западној половини сектора, док се у источној половини она постепено смањује

\footnotetext{
3 Чланови екипе били су П. Шпехар са Одељења за археологију Филозофског факултета у Београду, Г. Јањић из Музеја Крајине у Неготину, Ј. Пендић, докторанд на Одељењу за археологију Филозофског факултета у Београду, А. Дедић и Ј. Иванковић, студенткиње мастер студија на Одељењу за археологију Филозофског факултета у Београду, као и студенти археологије К. Миљковић, Д. Којић и Д. Симић.
} 


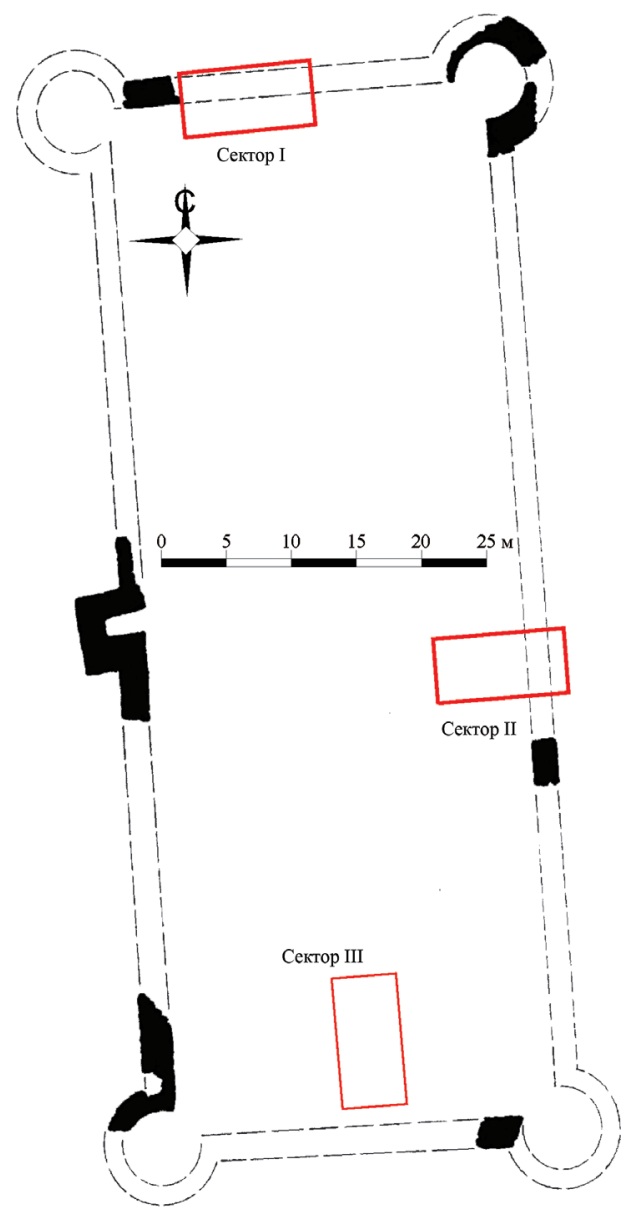

Сл. 4. Утврђење II са положајем ископаваних сектора (према Петровић 1984, сл. 142)

Fig. 4. Fortification II with the position of the excavated sectors (after Петровић 1984, сл. 142)

до 0,1 м дебљине. Испод ње се налази слој компактније глиновите земље дебљине до 0,2 м, у коме није било налаза и можда представља нивелацију терена. На споју шута избаченог приликом ранијих ископавања и поменуте компактније земље, откривен је анонимни фолис кован у време владавине Константина IX Мономаха (сл. 5A). ${ }^{4}$ Поменути примерак припада групи $C$

\footnotetext{
${ }^{4}$ Поменуто ковање, као и остале налазе новца откривене на Егети током кампање 2019, прочитао је и датовао академик В. Иванишевић, научни саветник Археолошког института у Београду, на чему му захваљујемо.
} 

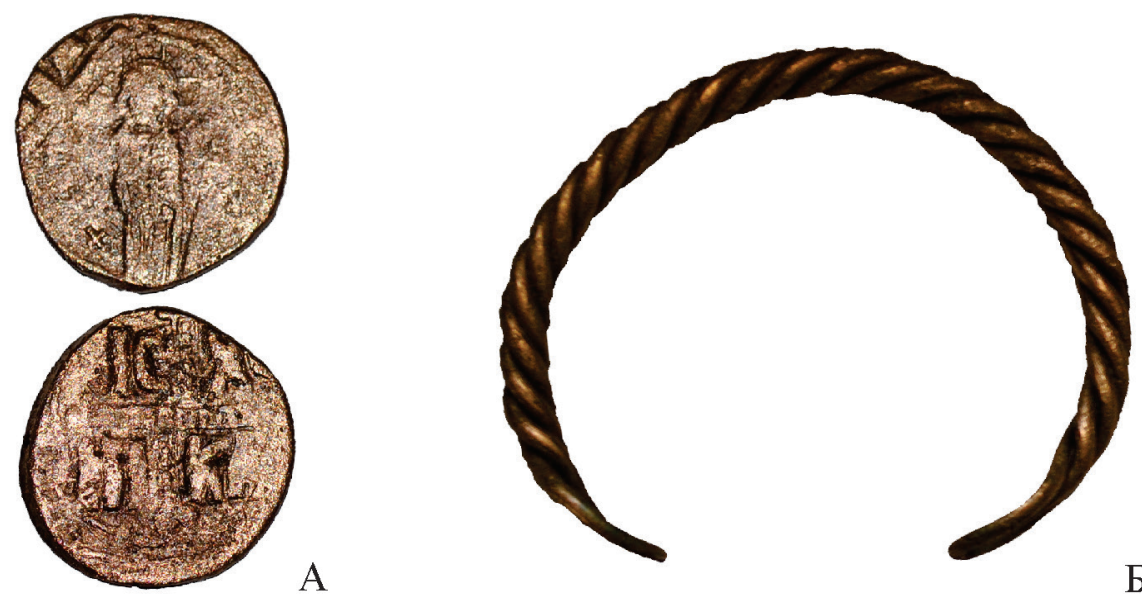

A

Б

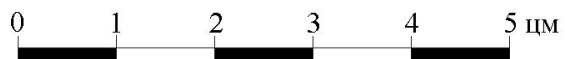

Сл. 5. А - Анонимни фолис (фото: Г. Јањић); Б - Наруквица (фото: Г. Јањић)

Fig. 5. A - Anonymous follis (photo: G. Janjić); Б - Bracelet (photo: G. Janjić)

анонимних фолиса, а кован је преко примерка анонимног фолиса групе $B$ (Grierson 1973, 681-684). Слични примерци познати су са различитих налазишта на територији Србије, пре свега њеног источног дела (Иванишевић 1993, 83-84; Радић, Иванишевић 2006, 178, кат. бр. 774-778). Испод слоја глиновите земље наишло се на слој беличастог малтера на претпостављеној траси бедема која се пружа кроз цео сектор, ширине око 2 м, док се северно и јужно од њега налази слој интензивно горелог шута црвене боје. Приликом уклањања слојева који су горели, чија је дебљина износила до 0,6 м, откривена је интензивна концентрација великих комада згуре, као и трагови горелог дрвета, од којих су поједини средње величине. По уклањању слоја горења са обе стране бедема, наишло се на слој жуте глиновите земље, који, како се чини, не представља здравицу, где су и окончана ископавања. У средишњем делу сектора се пак стало на поменутој зони интензивног шута ширине 2 м, који се од западне ивице пружа ка истоку у дужини од око 5,3 м, после чега се интензитет шута постепено смањује у дужини од 3,6 м, након чега се губи непосредно испред источног профила. Неопходно је напоменути да засад није констатована круна северног бедема, иако се стигло до коте на којој се јавља камена маса западно од сектора, за коју се претпоставља да припада бедему. Такође, у сектору I засад није уочено ни спољашње ни унутрашње лице бедема. Наставак ископавања у овом сектору планиран је за наредну кампању. 
Сектор II је такође имао димензије 10 х 5 м. Оријентисан својом дужом страном у правцу И-3 обухватао је квадрате G9 и Н9. Сектор је постављен управно на источни бедем, чију претпостављену трасу сече. Као и у претходном случају и овде је требало потврдити правац пружања бедема, али и утврдити стратиграфију утврђења и време њеног настанка. Током ископавања су, због конфигурације терена, у овом сектору издвојене три целине: источна, централна и западна. Све три су биле покривене површинским слојем хумуса дебљине 0,1 м. У источној зони, која се простире од источне ивице сектора у дужини од 5 м у правцу запада, најпре је констатован слој максималне дебљине око 0,7 м, у коме су осим керамичког материјала и животињских костију, откривени и бројни фрагменти турских лула, као и налази турског новца, који се везују за раздобље 18-19. век. Овај слој је делимично прекривао претпостављену трасу бедема, која се у Сектору II манфестовала у виду агломерације камена. Приликом истраживања поменутог слоја, констатовано је да се он налази и испод уочене агломерације камена, која се пружала у дужини од 5 м по правцу $\mathrm{C}-\mathrm{J}$, док joj је ширина износила око 0,8 м у северном, односно 1,3 м у јужном делу. Поменута агломерација се састојала од једног до два реда поређана камена средње величине повезаних земљом. Пошто је документована, агломерација је уклоњена и том приликом је констатовано да се $0,5-0,6$ м испод ње, на коти од $63,21 \mathrm{~m}$, налази више чаура метака пушке M-48. Том приликом је откривен и део платна некадашњег бедема неправилног облика начињен од камена везаног кречним малтером беле боје, димензија око 1,20 х 1,10 x 0,50 м. Поменуто откриће је указало да остаци камене масе видљиви на површини земље не представљају трасу источног бедема, већ неку врсту грудобрана који је ЈНА подигла овде педесетих и шездесетих година 20. века на траси некадашњег бедема. У наставку ископавања потврђено је да су и преостали слојеви у овом делу сектора, дебљине до 0,4 м, девастирани све до здравице у виду жуте глиновите земље, и да се у њима истовремено јављају налази из средњовековног периода, попут стаклених наруквица, као и они из раздобља турске доминације, о чему сведоче налази лула, те уломци рецентних стаклених флаша.

У централној зони сектора, која се пружала читавом његовом ширином, у дужини од 3 м у правцу запада од источне зоне, испод хумуса се налазио слој у коме су се првенствено јављали налази из периода турске доминације. Испод њега је само у једном делу сектора констатована горела црвена растресита земља, која се јавља на површини неправилног облика, димензиja 3 м (C-J) х 2-2,6 м (И-3). Поменута зона почиње на 4,8 м од источне иви- 

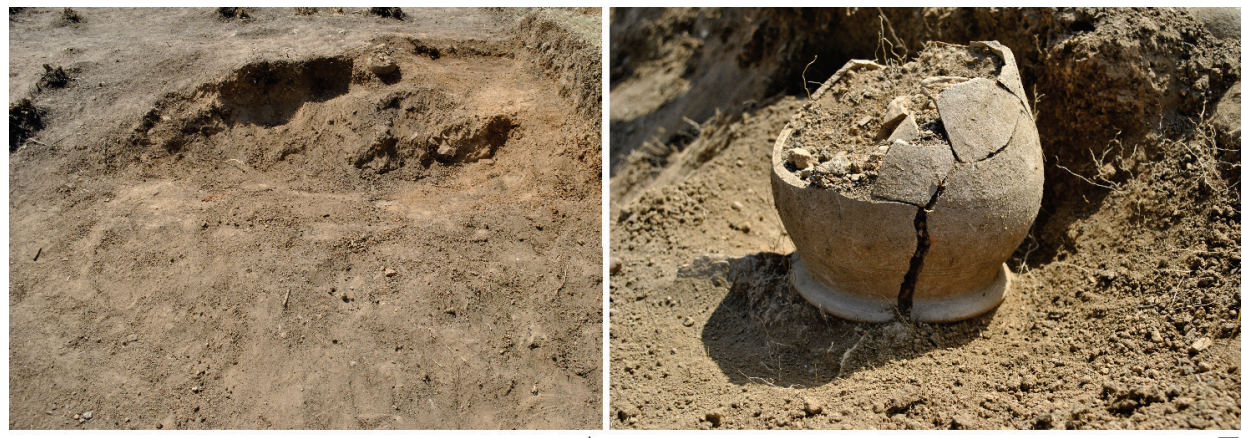

A

Сл. 6. А - Сектор II, слој рушења са керамичком посудом, поглед са истока (фото: А. Дедић); Б - керамичка посуда (фото: А. Дедић)

Fig. 6. A - Sector II, layer of destruction with a ceramic vessel, view from the east (photo: A. Dedić); Б - Ceramic vessel (photo: A. Dedić)

це сектора, одакле се пружа даље ка западу, и од северног профила, од кога се простире у правцу југа. У поменутом слоју, који је богат покретним налазима, пронађена је, између осталог, готово у потпуности очувана керамичка посуда окренута наопако (сл. 6/A), чији су садржај чиниле птичје кости и две стаклене перлице. Непосредно уз посуду налазио се вертикално пободен гвоздени нож. Биконична посуда мрке боје, украшена са три паралелне хоризонталне линије, начињена од фино печене керамике, по својим карактеристикама, тј. начину на који је обликован обод, као и према положају преласка горњег у доњи конус на трбуху (сл. 6/Б), може да се сврста у групу керамичких лонаца мањих димензија 12-13. века. Слични примерци, који су могли бити и богатије орнаментисани, познати су са локалитета Рудине (Поповић и Иванишевић 1988, 143-147, сл. 16/2-6), где су истоветно хронолошки опредељени. Керамичке посуде окренуте наопако, у којима се налазе остаци животињских костију, срећу се и на другим локалитетима у српском делу Подунавља у слојевима 12-13. века, као што је случај са налазиштима Морава $^{5}$ и Браничево. ${ }^{6}$ Ова појава по свему судећи представља археолошка сведочанства веровања ондашњих становника у српском делу Подунавља. Могуће је да зона на којој се јавља горела земља заправо представља слој рушења, идентичан оном који је констатован у Сектору I. Испод овог слоја, дебљине 0,15-0,3 м налазио се наредни слој са средњовековним налазима,

\footnotetext{
${ }^{5}$ Податак добијен усменим путем од руководиоца истраживања академика В. Иванишевића, научног саветника Археолошког института у Београду.

${ }^{6}$ Податак добијен усменим путем од руководиоца истраживања Д. Спасић-Ђурић, музејског саветника Народног музеја у Пожаревцу.
} 
дебљине око 15 цм, који належе на здравицу од жуте глине. Неопходно је истаћи да је са јужне и западне стране зоне са горелом земљом констатован ров укопан до нивоа здравице, у коме се истовремено јављају помешани налази из средњовековног раздобља и периода турске доминације.

У западној зони сектора је испод хумуса констатован девастирани слој у коме се јавља велика количина турских керамичких лула, али и налази средњовековног новца, опредељених у другу половину 12. и почетак 13. века, као и уломци стаклених наруквица карактеристичних за средњовековно раздобље, за чију израду је коришћено првенствено стакло црне боје. У прилог девастацији поменутог слоја сведочи и чињеница да су једни поред других на истој дубини откривани фрагменти турских лула и средњовековних стаклених наруквица. Поменути слој, дебљине око 0,6 м, такође је уклоњен до нивоа здравице у виду жуте глине.

Сектор III обухвата квадрате Е3 и Е4 и има димензије 10 (И-3) х 5 (С-J) м. Постављен је са унутрашње стране јужног бедема, како би се проверило постојање археолошких структура констатованих геомагнетним снимањем (сл. 7). Током истраживања уочено је да се на простору читавог сектора најпре јавља слој хумуса. Потом је у југозападном углу сектора констатован укоп из средине 20. века, димензија 1,3 (И-3) х 1 (J-C) м, у коме се јављају меци за пушку M-48, као и чауре оруђа за противваздушну одбрану калибра 20 мм. И овде су припадници ЈНА средином прошлог века укопали ров, а том приликом је уништен и јужни бедем некадашњег утврђења. Очувана дубина рова износи око 0,60 м. У преосталом делу сектора констатован је слој из периода турске доминације, дебљине $0,3-0,4$ м, који карактеришу првенствено сива керамика и налази турских лула, у коме се спорадично налазе и средњовековни налази, попут уломака стаклених наруквица. Испод поменутог слоја откривене су две средњовековне полуукопане куће. Прва, која се налази у СИ углу сектора има неправилан правоугаони облик, чије истражене димензије износе 2,4 (И-3) х 1,9 (С-J) м. Друга кућа се пружа уз источну ивицу сектора и јавља се на 2,6 м од јужне ивице сектора. Реч је о делимично истраженом стамбеном објекту, који најпре има правилан правоугаони облик ширине око 0,4 м, да би после 1,8 м пружања у правцу севера прерастао у неправилни кружни облик пречника око 2 м. У обема кућама су откривени остаци рушења, које карактерише тамна земља помешана са траговима горења, ситно измрвљеном опеком и комадима лепа. У њима се јавља и велика количина средњовековне керамике и животињских костију. У првој кући је на почетним котама слоја рушења констатована карактеристична средњовековна наруквица од четвороструко упредене жице. Такав 


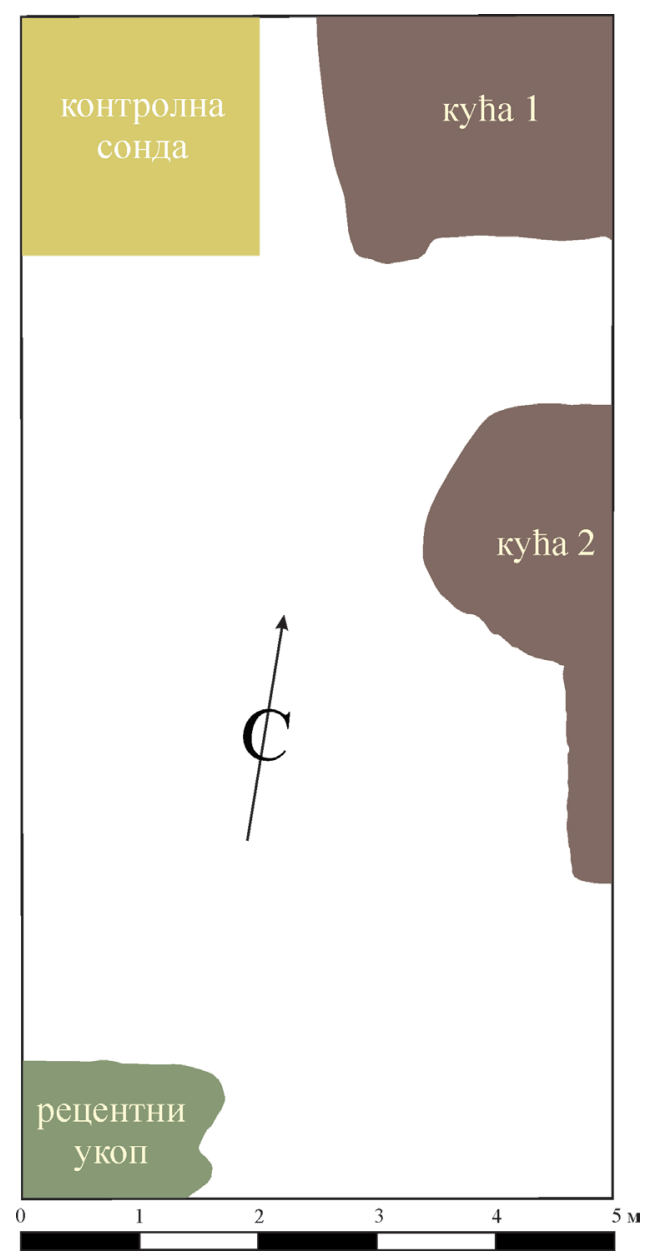

Сл. 7. Сектор III, основа

Fig. 7. Sector III, ground plan

тип се на територији Србије првенствено јавља на сеоским некрополама 12. века, мада је присутан и у каснијим раздобљима (Марјановић-Вујовић 1984, 98-99; Bikić 2010, 86). У испуни друге куће откривен је новац опредељен као латинска имитација византијских ковања, која се датује од 1204. до 1261. године. Обе куће припадају типу полуукопаних кућа, укопане на дубини од око 0,3 м у праисторијски слој, који се може везати за позни латен. Њега карактерише компактна глиновита земља жуто-мрке боје, изузетно тешка за копање, која је помешана са већом количином камена и уломцима шкољки. У слоју се поред керамичких налаза срећу и камени пројектили и керамички пршљенци. Како је овај слој био изузетно тежак за копање, услед недостатка 
времена у северозападном углу отворена је контролна сонда димензија 2 х 2 м, која је истражена до нивоа здравице од жуте глиновите земље. Овај стерилни слој прокопан је поменутим рецентним укопом у југозападном углу сектора. На основу тога утврђено је да слој жуте глиновите земље у којој нема налаза има максималну дебљину од 0,2 м, после чега се јавља црвенкаста стеновита земља, која убрзо прелази у стену.

$* * * * * * * * *$

Археолошка истраживања Егете спроведена током кампања 2018. и 2019. године, пружила су нове податке о овом значајном вишеслојном налазишту. Најпре је геомагнетним истраживањем утврђено да у зони где су, према речима мештана, налажени остаци људских скелета, нема зиданих гробница или гробова, већ су на њој уочени трагови археолошких структура различитог облика и димензија. На основу снимања спроведених унутар Утврђења II, у централном делу фортификације уочено је постојање велике камене конструкције димензија 50 х 6 м, као и постојање бројних археолошких структура различитих облика и величина.

Нао основу геомагнетних снимања и ситуације затечене на терену, спроведена су археолошка ископавања у три сектора димензија 10 х 5 м. Приликом археолошких ископавања, констатовано је да се најстарији хоризонт насељавања може везати за позни халштат, при чему су налази из овог раздобља констатовани само у јужном делу утврђења. Иако су спорадично констатовани уломци античке керамике, као и два новчића, од која један може да се определи у 4. век, током ископавања нису уочени јасни слојеви нити целине који би се могли везати за античко и касноантичко раздобље. Наредни хоризонт насељавања припада средњовековном периоду, чији се почеци на овом налазишту, судећи према расположивим налазима новца, могу везати за средину 11. века и представљају резултат поновне обнове византијске власти на простору централног Балкана у време владавине Василија II (976-1025), али и његових наследника. Нешто каснијем средњовековном раздобљу припадају остаци две делимично укопане куће у јужном делу утврђења, као и специфични налази попут керамичких посуда, уломака стаклених наруквица, бронзаних наруквица од преплетене жице, као и налаза новца, кованог у другој половини 12. и првој половини 13. века, када је ово утврђење, како се чини, играло значајну улогу. Неопходно је истаћи да део средњовековних налаза потиче из интензивног слоја рушења и горења, који сведоче о насилном престанку живота. Следе потом налази из позног раздобља турске доминације, о чему сведоче налази лула, као и једна сребрна аспра, која се везује за период 18-19. века. Истраживања су показала и да 
су припадници ЈНА потпуно девастирали источни и јужни бедем средином 20. века, кад су на поменутом простору укопали одбрамбени ров са каменим грудобраном. И даље остаје отворено питање времена настанка фортификације, за коју је још раније уочено да по својим карактеристикама одудара од осталих античких и касноантичких ђердапских утврђења (Поповић 1984, 158). Ипак, дебљина културних слојева, која је знатно већа од 0,4 до 0,5 м (Поповић 1984,157$)$, како је раније изнето, пружа могућност да се будућим истраживањима, пре свега на простору уз унутрашње лице западног бедема, утврди време настанка Утврђења II, које је сасвим сигурно имало значајну улогу током средњовековног раздобља.

\section{ИЗВОРИ}

It. Ant. 1929. Itineraria Romana I: Itineraria Antonini Augusti et Burdigalense, ed. O. Cuntz. Leipzig: Teubner.

Ptol. 1883. Claudii Ptolomae Geographia I, ed. C. Müllerus. Parisiis.

Tab. Peut. 1976. Tabula Peutingeriana I-II: Codex Vindobonensis 324, ed. E. Weber. Graz: Akademische Druck-u. Verlagsanstalt.

\section{БИБЛИОГРАФИЈА}

Bikić, V. 2010. Vizantijski nakit u Srbiji. Modeli i nasleđe. Beograd: Arheološki institut. Vučković-Todorović, D. 1962. Brza Palanka, Arheološki pregled 4: 208-210.

Вучковић-Тодоровић, Д. 1965. Светилиште Јупитера Долихена у Брзој Паланци, Старинар XV-XVI: 173-182.

Grierson, Ph. 1973. Catalogue of the Byzantine Coins in the Dumbarton Oaks Collection and in the Whittemore Collection, Volume 3.2, Leo III to Nicephorus III, 717-1081. Washington DC: Dumbarton Oaks Research Library and Collection.

Ерцеговић-Павловић, С. и Минић, Д. 1984. Брза Паланка, Сектори II и III (Извештај о археолошким истраживањима у 1980. години - средњи век), у: Бердапске свеске II, ур. В. Кондић, 167-170. Београд: Археолошки институт / Народни музеј / Одељење за археологију Филозофског факултета у Београду.

Иванишевић, В. 1993. Оптицаји византијских фолиса XI века на територији централног Балкана, Нумизматичар 16, 79-92.

Јањић, Г. 2016. Археологија Музеја Крајине. Неготин: Музеј Крајине.

Kanitz, F. 1892. Römische Studien in Serbia II. Wien: Kaiserlichen Akademie Wissenschaften in Wien.

Каниц, Ф. 1985. Србија, земља и становништво од римског доба до краја XIX века II. Београд: Српска књижевна задруга.

Марјановић-Вујовић, Г. 1980. Трњане. Српска некропола (крај IX-почетак XII века). Београд: Народни музеј. 
Marsigli, L. F. 1726. Danubius Pannonico-Mysicus Observationibus Geographicis, Oastronomicis, Hydrographicis, Phisicis Perlustratus I-II, Hagae.

Mirković, M. 1968. Rimski gradovi na Dunavu u Gornjoj Meziji. Beograd: Arheološko društvo Jugoslavije.

Mirković, M. 2007. Moesia Superior. Eine Provinz an der Mittleren Donau. Mainz: Verlag Philipp von Zabern.

Mirković, M. 2015. Rimljani na Đerdapu. Istorija i natpisi. Zaječar: Kairos.

Петровић, П. 1984. Брза Паланка - Егета (Извештај о археолошким истраживањима у 1980. години - антика), у Ђердапске свеске II, ур. В. Кондић, 153-159. Београд: Археолошки институт/Народни музеј/Одељење за археологију Филозофског факултета у Београду.

Petrović, P. 1986. Brza Palanka - Egeta. Recherches archéologique menées 1981-1982, у Ђердапске свеске III, ур. В. Кондић, 369-372. Београд: Археолошки институт/ Народни музеј/Одељење за археологију Филозофског факултета у Београду.

Поповић, М. и Иванишевић, В. 1988. Град Браничево у средњем веку, Старинар XXXIX: 125-179).

Поповић, П. 1984. Брза Паланка - Егета (Извештај о археолошким истраживањима у 1980. години - праисторија), у Ђердапске свеске II, ур. В. Кондић, 150. Београд: Археолошки институт/Народни музеј/Одељење за археологију Филозофског факултета у Београду.

Радић, В. и Иванишевић, В. 2006. Византијски новаи из Народног музеја у Београду. Београд: Народни музеј.

Радосављевић, С. 1984. Брза Паланка. Претходни извештај о антрополошком прегледу скелетних остатака, у Ђердапске свеске II, ур. В. Кондић, 175-177. Београд: Археолошки институт/Народни музеј/Одељење за археологију Филозофског факултета у Београду.

Špehar, P. 2010. Materijalna kultura iz ranovizantijskih utvrđenja u Đerdapu. Beograd: Arheološki institut.

Шпехар, П. 2018. Егета (Брза Паланка) - резултати истраживања 2017. године, Гласник Српског археолошког друштва 34: 56-71. 


\title{
Perica Špehar
}

University of Belgrade, Faculty of Philosophy,

Department of Archaeology, Belgrade

\section{Gordan Janjić}

Museum of Krajina, Negotin

\section{EGETA (BRZA PALANKA) - EXCAVATION RESULTS FROM 2018 AND 2019}

\author{
Keywords: Danube, Limes, Egeta, geomagnetic prospection, \\ medieval period, Ottoman period
}

Archaeological excavations of Egeta, conducted during the campaigns of 2018 and 2019, provided new data about this important multi-layered site. Primarily, via geomagnetic survey, it was established that no masonry graves or grave pits were discovered in the zone where, according to the testimonies of local inhabitants, human skeletal remains were unearthed, however, traces of archaeological structures of different shapes and sizes were registered. Based on the survey conducted within the central part of Fortification II, a large stone construction (dimensions: $50 \times 6 \mathrm{~m}$ ) was observed, as well as numerous archaeological structures of diverse shapes and dimensions.

During archaeological excavations, it was noticed that the oldest horizon of habitation can be linked to the late Hallstatt period. The finds dated into this period were discovered in the southern part of the fortification. Although shreds of Roman pottery were sporadically found, as well as two coins (one of which can be dated into the $4^{\text {th }}$ century), no clear horizon was discovered that could be tied to the said period. The following, clearly defined horizon of habitation, belonged to the Middle Ages, as testified by the remains of two semi dug-in houses in the southern part of the fortification, as well as by some specific finds such as ceramic pots, shreds of glass bracelets and five coins, the eldest of which is an anonymous follis dated into the middle of the $11^{\text {th }}$ century. The remaining coins were dated into the period of the second half of the $12^{\text {th }}$ and the first half of the $13^{\text {th }}$ century. It is necessary to emphasize that some of the medieval finds originate from a horizon of intensive demolition and burning, which is a testimony of the violent cease of active living here. There were also finds dated to the late Ottoman period, like pipes, for example, as well as one silver aspra, dated into the $18^{\text {th }} / 19^{\text {th }}$ century. Excavations showed that eastern and southern ramparts were destroyed in the mid- $20^{\text {th }}$ century by members of the Yugoslav National Army, who dug in a defensive trench with breastwork there. 
The important question is when the fortification was built. During the last quarter of the $20^{\text {th }}$ century, it was noticed that this fort was quite different from the rest of the Roman and Late Antique fortifications in the Iron Gates region. The thickness of cultural horizons is significantly larger than suggested $(0.4$ to $0.5 \mathrm{~m})$, which offers the possibility that the dating of Fortification II can be positively established by future excavations, primarily along the inner wall of the western rampart. The fortification certainly had an important role during the medieval period. 